\title{
Implikasi dan Akibat Hukum Putusan Mahkamah Konstitusi Nomor 69/Puu-Xiii/2015 terhadap Pembuatan Akta Perjanjian Perkawinan Setelah Kawin yang Dibuat di Hadapan Notaris
}

\author{
Eva Dwinopianti \\ Magister Kenotariatan, Universitas Islam Indonesia \\ Jl. Cik Di Tiro No. 1 Yogyakarta \\ evadwinop@yahoo.co.id
}

\begin{abstract}
This study aims to determine the implications of the Constitutional Court Decision No. 69 / PUU-XII / 2015 and the legal consequences for making the marriage contract after the Constitutional Court ruling on the status of property and third parties who feel aggrieved over the agreement. This study is a normative by using approaches Act (statuteapproach) and the conceptual approach (conseptualapproach). The data used is secondary data in the form of primary legal materials, secondary and tertiary. The results showed that the implications of the Constitutional Court Decision No.69 / PUUXIII / 2015 against the deed covenant marriage after the wedding before a Notary change the legal mechanism of making the marriage contract that can now be created during the marriage bond takes place by the Notary without preceded by court decision authorized. While the legal consequences of the marriage covenant deed after mating before the Constitutional Court ruling that the changes to the property status of husband and wife and binding upon both parties and against third parties. Later than it was after the Constitutional Court the legal consequences of making the marriage contract after the wedding on the status of joint property inherent (closely related) to the time of entry into force of the agreement and binding on third parties.
\end{abstract}

Keywords: Marital agreement, the notary, the constitutional court's decision

\begin{abstract}
Abstrak
Penelitian ini bertujuan untuk mengetahui implikasi Putusan Mahkamah Konstitusi Nomor 69/PUUXII/2015 dan akibat hukum atas pembuatan perjanjian perkawinan pasca Putusan MK terhadap status harta dan pihak ketiga yang merasa dirugikan atas perjanjian tersebut. Penelitian ini merupakan penelitian normative dengan menggunakan pendekatan Undang-undang (statute approach) dan pendekatan konseptual (conseptual approach). Data yang digunakan adalah data sekunder yang berupa bahan hukum primer, sekunder dan tersier. Hasil penelitian menunjukkan bahwa implikasi Putusan Mahkamah Konstitusi Nomor 69/PUU-XIII/2015 terhadap pembuatan akta perjanjian perkawinan setelah kawin yang dibuat dihadapan Notaris merubah mekanisme hukum pembuatan perjanjian perkawinan yang kini dapat dibuat selama ikatan perkawinan berlangsung oleh Notaris tanpa harus di dahului dengan penetapan pengadilan yang berwenang. Sedangkan akibat hukum pembuatan akta perjanjian perkawinan setelah kawin sebelum Putusan MK yaitu terjadinya perubahan terhadap status harta suami-istri dan mengikat kedua belah pihak serta terhadap pihak ketiga. Kemudian daripada itu pasca Putusan MK akibat hukum pembuatan perjanjian perkawinan setalah kawin terhadap status harta bersama inheren (berkaitan erat) dengan waktu mulai berlakunya perjanjian tersebut dan mengikat terhadap pihak ketiga.
\end{abstract}

Kata-kata Kunci : Perjanjian perkawinan, notaris, putusan mahkamah konstitusi

\section{Pendahuluan}


Perkawinan merupakan suatu perbuatan hukum dimana para pihak yang dapat melakukannya telah ditentukan oleh hukum dan terhadapnya akan menimbulkan suatu akibat hukum bagi para pihak tersebut. Perbuatan hukum demikian ituakan melahirkan hak dan kewajiban bagi suami dan istri yang telah berjanji mengikatkan diri satu sama lain secara lahir dan batin dan oleh karenanya akan mempunyai akibat hukum bagi kedua pihak tersebut. Perkawinan yang sah menurut hukum adalah suatu perbuatan hukum, sehingga konsekuensi bagi setiap perbuatan hukum yang sah akan menimbulkan akibat hukum bukan saja bagi kedua belah pihak suami istri namun juga bagi pihak lain dengan siapa salah satu pihak atau kedua-duanya (suami-istri) tersebut akan mengadakan hubungan hukum dikemudian hari. Dengan demikian perkawinan itu merupakan salah satu perbuatan hukum dalam masyarakat, yaitu peristiwa kemasyarakatan yang oleh hukum diberikan akibatakibat.

Setelah berlakunya Undang-Undang Nomor 1 Tahun 1974 tentang Perkawinan sebagai suatu unifikasi hukum dibidang perkawinan yang menganut asas perpisahan harta sebagaimana yang diatur pada ketentuan Pasal 35 ayat (1) disebutkan bahwa harta benda yang diperoleh selama perkawinan menjadi harta bersama dan pada ayat (2) selanjutnya menyebutkan bahwa harta masing-masing suami dan istri, dan harta benda yang diperoleh masing-masing sebagai hadiah atau warisan adalah dibawah penguasaan masing-masing sepanjang tidak ditentukan lain. Terlihat diantara ketentuan yang diatur oleh UndangUndang Nomor 1 Tahun 1974 tentang Perkawinan dengan KUHPerdata terdapat perbedaan, dimana didalam KUHPerdata mengatur kekayaan dari suami dan istri yang dibawa kedalam perkawinan dicampur menjadi harta persatuan, yaitu harta kekayaan bersama diantara mereka, sedangkan didalam Undang-Undang Nomor 1 Tahun 1974 tentang Perkawinan harta perkawinan yang dibawa kedalam perkawinan (harta bawaan) tetap menjadi milik masing-masing dan yang tercampur menjadi satu hanyalah harta yang diperoleh dari dan/atau selama perkawinan berlangsung (harta gono gini).

Namun disamping itu terdapat persamaan diantara peraturan tersebut yaitu, kedua peraturan tersebut memberikan kesempatan bagi pasangan suami-istri memutuskan untuk menentukan lain terhadap harta baik yang diperoleh sebelum dan/atau setelah berlangsungnya perkawinan, hal ini merupakan suatu penyimpangan yang dibenarkan oleh hukum yang ditentukan secara limitatif melalui pembuatan perjanjian perkawinan.

Perjanjian Perkawinan atau sering disebut dengan perjanjian pra nikah tersebut dikenal dalam KUHPerdata maupun Undang-Undang Nomor 1 Tahun 1974 tentang 


\section{IEX Renaissance No. 1 VOL. 2 JANUARI 2017: 16 - 34}

Perkawinan yang merupakan suatu perjanjian yang dibuat oleh sepasang calon suami istri dihadapan notaris yang menyatakan bahwa mereka telah sepakat untuk membuat pemisahan atas harta benda mereka masing-masing dalam perkawinan mereka kelak, maka setelah dibuatnya perjanjian tersebut maka semua harta baik yang diperoleh sebelum maupun selama berlangsungnya perkawinan kelak adalah hak dan tetap menjadi milik mereka masing-masing, demikian pula dengan hutang-piutang dari masing-masing pihak teresebut kan tetap menjadi hak dan tanggungjawab dari masing-masing pihak yang memiliki hutang piutang tersebut.

Hal tersebut sesuai dengan ketentuan dalam KUHPerdata pada Pasal 139 yang menyebutkan bahwa“dengan mengadakan perjanjian perkawinan, kedua calon suami isteri adalah berhak menyiapkan beberapa penyimpangan dari peraturan undang-undang sekitar persatuan harta kekayaan, asal perjanjian itu tidak menyalahi tata susila yang baik atau tata tertib umum dan asal diindahkan pula segala ketentuan di bawah ini”. Artinya bahwa Perjanjian perkawinan adalah perjanjian mengenai pengaturan terhadap harta benda suamiisteri yang diperoleh baik sebelum dan selama perkawinan mereka berlangsung, yang merupakan suatu penyimpangan yang dibenarkan oleh hukum dari asas atau pola yang ditetapkan oleh undang-undang.

Mengenai syarat perjanjian perkawinan itu diatur pada Pasal 29 Undang-Undang Nomor 1 Tahun 1974 Tentang Perkawinan yang pada intinya menyebutkan bahwaperjanjian perkawinan harus dibuat dengan akta notaris, maupun dengan perjanjian tertulis yang disahkan oleh Petugas Pencatat Perkawinan, sebelum perkawinan itu berlangsung atau pada saat perkawinan berlangsung dan Perjanjian Perkawinan tersebut mulai berlaku sejak perkawinan itu dilangsungkan, serta tidak dapat dirubah, kecuali dari kedua belah pihak ada persetujuan untuk merubah dan perubahan tidak merugikan pihak ketiga. Apabila pendaftaran perjanjian tersebut di Kepaniteraan Pengadilan Negeri belum juga dilakukan dan belum dicatat dalam Akta Perkawinan Catatan Sipil, maka para pihak ketiga boleh menganggap suami-isteri itu kawin dalam percampuran harta kekayaan.

Perjanjian perkawinan yang dibuat sebelum perkawinan pada saat ini bukan lagi menjadi suatu hal yang tabuh bagi masyarakat Indonesia, apalagi para notaris sudah terbiasa untuk membuat akta perjanjian pernikahan tersebut, dilaksankannya hal tersebut sematamata untuk melindungi harta benda yang diperoleh masing-masing pihak, agar dikemudian hari terhadap konsekuensi hukum atas suatu perbuatan hukum dapat dipertanggungjawabkan oleh masing-masing pihak yang melakukannya sehingga tidak melibatkan harta yang diperoleh masing-masing pihak. 
Namun hal yang menarik dari perjanjian perkawinan ini ialah dalam hal pelaksanaan perjanjian perkawinan, dimana berdasarkan ketentuan yang diatur baik dalam KUHPerdata Pasal 147 maupun Undang-Undang Perkawinan pada Pasal 29 menyebutkan bahwa perjanjian perkawinan dilaksanakan pada waktu atau sebelum perkawinan dilangsungkan, namun fenomena yang terjadi dimasyarakat bahwa adanya perjanjian perkawinan dilaksanakan setelah perkawinan tersebut berlangsung berdasarkan penetapan pengadilan, seperti halnya Penetapan Pengadilan Negeri Jakarta Timur Nomor 207/Pdt/P/2005/ PN.Jkt.Tim., dan Penetapan Pengadilan Negeri Jakarta Timur Nomor 459/Pdt/P/2007/PN.Jkt.Tim.

Berdasarkan ketentuan Pasal 186 KUHPerdata di atas bahwa secara hukum, perjanjian perkawinan yang dibuat setelah dilaksanakannya perkawinan dianggap sah menurut hukum apabila telah mendapatkan penetapan pengadilan terlebih dahulu, dengan alasan yang telah ditentukan. Hal ini menimbulkan suatu ketidakpastian hukum, karena berdasarkan Pasal 147 KUHperdata maupun Undang-Undang Perkawinan pada Pasal 29 secara eksplisit menyebutkan bahwa perjanjian perkawianan dapat dilaksanakan pada saat atau sebelum perkawinan tersebut dilangsungkan.

Pada tanggal 27 Oktober 2016 Mahkamah Konstitusi (MK) melalui putusannya Nomor 69/PUU-XIII/2015 memberi tafsir konstitusional terhadap Pasal 29 ayat (1), (3), dan (4) Undang-Undang Nomor 1 Tahun 1974 tentang Perkawinanatas permohonan Ny. Ike Faridayang inti amarnya menyebutkan bahwa sepanjang tidak dimaknai perjanjian pernikahan dapat dilangsungkan "selama dalam ikatanperkawinan", maka Pasal demikian itu menurut Mahkamah tidak mempunyai kekuatan hukum mengikat (inkonstitusional bersyarat).

Artinya bahwa berdasarkan Putusan MK tersebut terhadap Pasal 29 ayat (1), (3), dan (4) Mahkamah menerapkan interpretasi ekstensif sehingga mengakibatkan rumusan norma dalam Pasal 29 ayat (1), (3), dan (4) terhadap pelaksanaan perjanjian perkawinan kini tidak terbatas hanya dapat dilaksanakan pada waktu atau sebelum perkawinan tersebut dilangsungkan, melainkan juga selama dalam ikatan perkawinanan pun perjanjian perkawinan dapat dilaksanakan oleh suami-istri atas persetujuan bersama. Dengan demikian dalam hal ini MK mengedepankan penerapan hukum progresif untuk memenuhi kebutuhan hukum atas fenomena yang terjadi di masyrakat terhadap resiko-resiko yang mungkin saja dapat timbul dari harta bersama dalam perkawinan, baik dikarenakan pekerjaan suami dan 


\section{IEx Renaissance No. 1 VOL. 2 JANUARI 2017: 16 - 34}

istri yang memiliki konsekuensi dan tanggung jawab sampai pada harta pribadi, maupun dikarenakan akibat hukum atas Pasal 21 ayat (1) dan (3) UUPA.

Perjanjian Perkawinan setelah kawin sebelumnya tidak dikenal atau diatur dalam Undang-Undang Nomor 1 Tahun 1974 tentang Perkawinan, namun pasca Putusan MK terhadap Pasal 29 ayat (1), (3), dan (4) yang menurut Mahkamahharuslah dimaknai juga dapat dilakukan pada saat telah berlangsungnya ikatan perkawinan apabila ada persetujuan bersama antara suami dan istri, hal ini akan menjadi permasalahan hukum ketika Putusan MK tersebut dihadapkan dengan ketentuan Pasal 186 KUHPerdata yang mengatur proses pembuatan Akta Perjanjian Kawin setelah kawin (pemisahan harta) yang harus mendapatkan penetapan pengadilan terlebih dahulu.

Berdasarkan latar belakang tersebut di atas maka menjadi penting untuk dikaji lebih jauh implikasi hukum atas Putusan MK yang mempengaruhi sistem hukum perjanjian perkawinan yang telah diatur dalam Undang-Undang Nomor 1 Tahun 1974 tentang Perkawinan, dimana pasca Putusan MK mengalami perubahan secara maknawi terhadap Pasal 29 ayat (1), (3), dan (4) yang menurut Mahkamah haruslah dimaknai juga dapat dilakukan pada saat telah berlangsungnya ikatan perkawinan apabila ada persetujuan bersama antara suami dan istri, hal demikian tersebut akan berimplikasi terhadap pembuatan Akta Perjanjian Perkawinan selama dalam ikatan perkawinan oleh notaris dan akibat hukum dari perjanjian perkawinan terhadap status harta yang telah menjadi harta bersama serta terhadap pihak ketiga, hal inilah yang menjadi perhatian penulis sehingga menarik untuk ditelusuri dan dikaji.

\section{Rumusan Masalah}

Berangkat dari uraian di atas, maka rumusan masalah dalam penelitian ini di antaranya, pertama, bagaimana implikasi Putusan Mahkamah Konstitusi Nomor 69/PUUXIII/2015 terhadap pembuatan akta perjanjian perkawinan setelah kawin yang dibuat di hadapan Notaris?. Kedua, bagaimana akibat hukum pembuatan akta perjanjian perkawinan setelah kawin sebelum dan pasca Putusan Mahkamah Konstitusi Nomor 69/PUU-XIII/2015 terhadap status harta bersama dan pihak ketiga yang dibuat di hadapan Notaris?

\section{Tujuan Penelitian}

Untuk mengetahui implikasi Putusan akibat hukum pembuatan akta perjanjian perkawinan setelah kawin sebelum dan pasca Mahkamah Konstitusi Nomor 69/PUU- 
XIII/2015 terhadap pembuatan akta perjanjian perkawinan setelah kawin yang dibuat dihadapan notaris.

\section{Metode Penelitian}

Penelitian ini merupakan penelitian normatif dengan menggunakan pendekatan Undang-undang (statute approach) dan pendekatan konseptual (conseptual approach). Data yang digunakan adalah data sekunder yang berupa bahan hukum. Bahan hukum adalah informasi atau keterangan yang benar mengenai objek penelitian yang terdiri dari bahan hukum primer, bahan hukum sekunder, dan bahan hukum tersier, ${ }^{1}$ oleh karena itu bahan hukum yang akan digunakan dalam penelitian ini adalah bahan hukum primer yang terdiri dari peraturan perundang-undangan yang terkait dengan objek penelitian seperti UndangUndang Nomor 1 Tahun 1974 Tentang Perkawinan, Peraturan Pemerintah Pelaksana Republik Indonesia Nomor 9 Tahun 1975 Tentang Pelaksanaan Undang-Undang Nomor 1 Tahun 1974 dan Putusan Mahkamah Konstitusi Nomor69/PUU-XIII/2015 tanggal 27 Oktober 2016. Bahan hukum sekunder yang terdiri dari buku-buku dan diktat-diktat literatur tentang Perdata, Perkawinan, dan serta, yakni bahan-bahan hukum berupa tulisan-tulisan hukum yang dalam bentuk buku, hasil-hasil penelitian, disertasi, jurnal, makala, artikel, dan bahan-bahan hukum sekunder lainnya yang berkaitan dengan objek penelitian. Bahan hukum tersier, yang terdiri dari bahan hukum yang berisi penjelasan arti tentang berbagai istilah-itilah yang terkait dengan objek penelitian ini, yaitu kamus hukum, kamus bahasa Indonesia.

Pengumpulan bahan hukum untuk penelitian ini menggunakan teknik Studi Dokumen. Yaitu melakukan penelitian terhadap dokumen-dokumen yang erat kaitannya dengan objek penelitian guna mendapatkan landasan teoritis dan memperoleh informasi dalam bentuk ketentuan formal dan melalui naskah resmi yang ada. Selanjutnya teknik pengumpulan data dengan menggunakan studi dokumen ini didukung dengan teknik pengumpulan data melalui wawancara, Yaitu mengadakan tanya jawab secara langsung kepada pihak-pihak yang ada kaitannya dengan objek penelitian. Setelah bahan hukum terkumpul kemudian dinalisis secara kualitatif, yaitu dari bahan hukum yang diperoleh kemudian disusun secara sistimatis kemudian dianalisa secara kualitatif untuk mencapai kejelasan terhadap masalah yang akan dibahas. Analisis kualitatif adalah suatu cara

${ }^{1}$ Suryono Sukanto \& Sri Mamuji, Penelitian Hukum Normatif, cet empat balas (Jakarta: PT Raja Grafindo Persada, 2012), hlm. 12-13. 


\section{IEx Renaissance No. 1 VOL. 2 JANUARI 2017: 16 - 34}

menganalisis bahan hukum penelitian yang menghasilkan data deskriptif analisis. Pengertian analisis disini dimaksudkan sebagai suatu penjelasan dan penginterpretasian secara logis, sistimatis. Logis sistimatis menunjukan cara berpikir deduktif-induktif dan mengikuti tata tertib dalam penulisan penelitian ilmiah. Setelah analisi data selesai maka hasilnya akan disajikan secara deskriptif, yaitu dengan menuturkan dan menggambarkan apa adanya sesuai dengan permasalahan yang diteliti. ${ }^{2}$

\section{Hasil Penelitian Dan Pembahasan}

\section{Implikasi Putusan Mahkamah Konstitusi Nomor 69/PUU-XIII/2015 Terhadap Pembuatan Akta Perjanjian Perkawinan Setelah Kawin Yang Dibuat di Hadapan Notaris}

Ketentuan mengenai pembuatan perjanjian perkawinan yang diatur di dalam Undang-Undang Nomor 1 Tahun 1974 tentang Perkawinan tidak mengatur mengenai pembuatan perjanjian perkawinan setelah kawin dilangsungkan. Ketentuan dalam Pasal 29 Undang-Undang tersebut yang pada intinya hanya mengatur mengenai perjanjian perkawinan yang dapat dibuat pada waktu atau sebelum perkawinan dilangsungkan, namun dalam fenomena perkembangannya di masyrakat (praktek) dapat ditemui perjanjian perkawinan yang dibuat pada saat ikatan perkawinan berlangsung yang dengan alasan tertentu antara suami-istri tersebut baru membuat perjanjian perkawinan, adapun hal demikian tersebut dapat dibenarkan oleh hukum dengan dasar bahwa perjanjian demikian itu haruslah didahului dengan mangajukan permohonan ke pengadilan yang berwenang agar mendapatkan suatu penetapan dari hakim, seperti penetapan pengadilan di bawah ini yaitu: 1. Penetapan Pengadilan Negeri Jakarta Timur Nomor 207/Pdt/P/2005/ PN.Jkt.Tim., dan 2. Penetapan Pengadilan Negeri Jakarta Timur Nomor 459/Pdt/P/2007/PN.Jkt.Tim.

Selanjutnya setelah mendapatkan penetapan pengadilan tersebut para pihak (suamiistri) barulah dapat membuat akta perjanjian perkawinan setelah kawin kehadapan Notaris. Karena berdasarkan Pasal 15 ayat (1) Undang-Undang Nomor 2 Tahun 2014 tentang Perubahan atas Undang-Undang Nomor 30 Tahun 2004 tentang Jabatan Notaris menyebutkan bahwa Notaris berwenang membuat akta otentik mengenai semua perbuatan, perjanjian, dan ketetapan yang diharuskan oleh peraturan perundang-undangan dan/atau yang dikehendaki oleh yang berkepentingan untuk dinyatakan dalam akta otentik, menjamin kepastian tanggal pembuatan akta, menyimpan akta, memberikan grosse, salinan dan

${ }^{2}$ H.B. Sutopo. Metodologi Penelitian Hukum Kualitaif Bagian II, (Surakarta : UNS Press, 1998), hlm. 37. 
kutipan akta, semuanya itu sepanjang pembuatan akta-akta itu tidak juga ditugaskan atau dikecualikan kepada pejabat lain atau orang lain yang ditetapkan oleh Undang-Undang.

Oleh karena itu bila dikaitkan antara Pasal tersebut (kewenangan Notaris) dengan perjanjian perkawinan setelah kawin yang telah terlebih dahulu mendapatkan penetapan dari pengadilan, maka dapat diartikan bahwa walaupun perjanjian demikian itu dilaksanakan pada saat perkawinan berlangsung dengan terlebih dahulu mendapatkan penetapan dari pengadilan namun tidak mengurangi esensi dari wewenang Notaris sebagai pejabat umum ${ }^{3}$ dalam pembuatan akta perjanjian perkawinan tersebut. Kemudian daripada itu akta perjanjian yang telah dibuat di hadapan Notaris tersebut didaftarkan pada instansi yang diberi wewenang oleh peraturan perundang-undangan untuk mencatatkannya yaitu Dinas Kependudukan dan Pencatatan Sipil atau Kantor Urusan Agama (KUA) sesuai subjek hukumnya. ${ }^{4}$ Jika akta perjanjian perkawinan tersebut kemudian tidak didaftarkan maka dengan sendirinya secara hukum tidak mengikat bagi pihak ketiga.

Hal demikian itu sesuai dengan ketentuan Pasal 29 ayat (1) Undang-Undang Perkawinan, perjanjian perkawinan disahkan oleh Pegawai Pencatat Perkawin. Menurut Alwesius "disahkan" dalam kalimat ketentuan Pasal 29 ayat (1) Undang-Undang Perkawinan tidak berarti apabila perjanjian perkawinan tersebut tidak disahkan oleh Pegawai Pencatat Perkawinan maka perjanjian perkawinan tersebut tidak sah. Menurutnya "disahkan" dalam kalimat tersebut artinya adalah bahwa perjanjian perkawinan tersebut harus "dicatat", dan apabila perjanjian perkawinan tersebut tidak dicatat maka perjanjian perkawinan tersebut tidak mengikat pihak ketiga. ${ }^{5}$

Namun pasca keluarnya putusan Mahkamah Konstitusi Nomor 69/PUU-XIII/2015 tanggal 21 Maret 2016 terjadi perubahan yang berkaitan dengan pembuatan perjanjian perkawinan, putusan tersebut atas permohonan seorang warga negara Indonesia yang melakukan perkawinan campuran, yang melangsungkan perkawinan dengan tanpa membuat perjanjian perkawinan. Seiring waktu berjalan pasangan tersebutpun bermaksud untuk membeli rumah/rumah susun, akan tetapi karena peraturan yang berlaku dalam konteks

${ }^{3}$ Pasal 1 ayat (1) Undang-Undang Nomor 30 Tahun 2004 tentang Jabatan Notaris sebagaimana telah diubah dengan Undang-Undang Nomor 2 Tahun 2014 tentang Perubahan atas Undang-Undang Nomor 30 Tahun 2004 tentang Jabatan Notaris menyebutkan bahwa Notaris adalah Pejabat Umum yang berwenang untuk membuat akta otentik dan kewenangan lainnya sebagaimana dimaksud dalam Undang-Undang ini.

${ }^{4}$ Setelah diundangkannya Undang-Undang Perkawinan (tanggal 2 Januari 1974/setidak-tidaknya sesudah berlakunya Peraturan Pemerintah Nomor 9 Tahun 1975) perjanjian perkawinan dicatatkan di Kantor Catatan Sipil atau Kantor Urusan Agama.

5 Alwesius, Pembuatan Perjanjian Perkawinan Pasca Putusan Mahkamah Konstitusi bttp:// alwesius.blogspot.co.id/2016/11/pembuatan-perjanjian-perkawinan-pasca.html, diakses pada tanggal 3 Januari 2017. 
hukum tanah nasional yaitu ketentuan pada UUPA dianutnya asas nasionalitas, yang artinya bahwa hanya WNI saja yang bisa memiliki hak atas tanah di Indonesia. Oleh karena itu kemudian pasangan perkawinan campuran tersebut mengajukan permohonan constitutional review (pengujian konstitusional) ke Mahkamah Konstitusional kerana tela merasa dirugikan dengan adanya Pasal 21 ayat (1), dan ayat (3), Pasal 36 ayat (1) UUPA, Pasal 29 ayat (1), ayat (3), ayat (4), ayat dan Pasal 35 ayat (1) Undang-Undang Perkawinan.

Selanjutnya atas permohonan demikian itu MK berpendapat dalam pertimbangan hukumnya menyebutkan bahwa: Tegasnya, ketentuan yang ada saat ini hanya mengatur perjanjian perkawinan yang dibuat sebelum atau pada saat perkawinan dilangsungkan, padahal dalam kenyataannya ada fenomena suami-istri yang karena alasan tertentu baru merasakan adanya kebutuhan untuk membuat perjanjian kawin selama dalam ikatan perkawinan. Selama ini sesuai dengan Pasal 29 Undang-Undang Nomor 1 Tahun 1974 perjanjian demikian itu harus diadakan sebelum perkawinan dilangsungkan dan harus diletakkan dalam suatu akta Notaris. Perjanjian Perkawinan ini mulai berlaku antara suami dan istri sejak perkawinan dilangsungkan. Isi yang diatur di dalam Perjanjian perkawinan tergantung pada kesepakatan pihak-pihak calon suami dan istri, asal tidak bertentangan dengan Undang-Undang, agama, dan kepatutan atau kesusilaan, adapun terhadap bentuk dan isi perjanjian perkawinan, kepada kedua belah pihak diberikan kebebasan atau kemerdekaan seluas-luasnya (sesuai dengan hukum "kebebasan berkontrak").

Frasa "pada waktu atau sebelum perkawinan dilangsungkan" dalam Pasal 29 ayat (1), frasa”... sejak perkawinan dilangsungkan" dalam Pasal 29 ayat (3), dan frasa "selama perkawinan berlangsung” dalam Pasal 29 ayat (4) Undang-Undang Nomor 1 Tahun 1974 membatasi kebebasan 2 (dua) orang individu untuk melakukan atau kapan akan melakukan "perjanjian", sehingga bertentangan dengan Pasal 28 E ayat (2) UUD 1945 sebagaimana didalilkan pemohon. Dengan demikian, frasa "pada waktu atau sebelum perkawinan dilangsungkan" dalam Pasal 29 ayat (4) Undang-Undang Nomor 1 Tahun 1974 adalah bertentangan dengan UUD 1945 secara bersyarat sepanjang tidak dimaknai termasuk pula selama dalam ikatan perkawinan.

Putusan MK yang demikian itu, akan memperoleh kekuatan hukum tetap dan mengikat sejak setelah diucapkan dihadapan sidang terbuka untuk umum, ${ }^{6}$ yang berarti bahwa, putusan MK langsung memperoleh kekuatan hukum tetap dan mengikat setelah

${ }^{6}$ Indonesia, Pasal 47 Undang-Undang Nomor 24 Tahun 2003 tentang Mabkamah Konstitusi sebagaimana telah diubah dengan Undang-Undang Nomor 8 Tahun 2011 tentang Perubahan Atas Undang-Undang Nomor 24 Tahun 2003 tentang Mahkamah Konstitusi. 
diucapkan dan tidak ada upaya hukum lain yang dapat ditempuh (final and binding). Akibat hukum Putusan MK di atas yang mengabulkan permohonan Pemohon ialah batal dan tidak mempunyai kekuatan hukum mengikat terhadap suatu norma hukum yang dimohonkan oleh Pemohon, oleh karena itu dalam hal ini Pasal 29 ayat (1), (3), dan (4) Undang-Undang Nomor 1 Tahun 1974 tentang Perkawinan berdasarkan amar Putusan MK di atas inkonstitusional bersyarat, sehingga putusan yang demikian itu menciptakan suatu keadaan hukum baru (dekclaratoir constitutif) yang dalam hal ini MK sebagaimana disebut oleh Hans Kelsen sebagai negatif-legislator, sehingga Putusan MK tersebut sama dengan perintah konstitusi.

Adapun kekuatan hukum dari Putusan MK terdiri dari kekuatan hukum mengikat, kekuatan hukum pembuktian, dan kekuatan hukum eksekutorial. Kekuatan hukum mengikat pada Putusan MK tidak hanya mengikat pihak-pihak berperkara (interpartes), tetapi juga mengikat dan/atau ditujukan bagi semua warga negara, lembaga/pejabat negara dan badan hukum dalam wilayah Republik Indonesia (erga omnes). Oleh karena itu berdasarkan penjelasan tersebut Putusan MK juga mengikat bagi Notaris selaku yang memiliki wewenang (pejabat) dalam pembuat akta perjanjian perkawinan dan Dinas Kependudukan dan Pencatatan Sipil atau Kantor Urusan Agama (KUA) selaku pejabat yang memiliki wewenang untuk mencatatkan akta perjanjian perkawinan tersebut.

Fenomena yang terjadi dimasyrakat tersebut yang menjadi salah satu pertimbangan Mahkamah Konstitusi untuk menyatakan pasal-pasal demikian itu inkonstitusional bersyarat sebagaimana pertimabangan hukum Mahkamah Konstitusi yang telah di uraikan di atas, hal ini semata-mata dilakkukan Mahkamah Konstitusi guna memberikan kepastian hukum dan keadilan yang dijamin oleh UUD 1945 bagi masyarakat atas hak konstitusionalnya dalam membuat suatu perjanjian (asas kebebasan berkontrak) dalam hal ini perjanjian perkawinan, oleh karena itu Mahkamah Konstitusi melalui salah satu kewenangannya yang diatur dalam Pasal 24 C ayat (1) UUD 1945 yaitu menguji UndangUndang terhadap UUD 1945 mengeluarkan suatu Putusannya yang progresif untuk mengakomodir kebutuhan hukum dimasyarakat.

Namun demikian terkait pencatatan perjanjian perkawinan yang dibuat sepanjang perkawinan harus diperhatikan juga bahwa di dalam praktek ternyata masih terdapat hambatan-hambatan teknis didalam melakukan pencatatan perjanjian perkawinan tersebut, ini terjadi karena ternyata ada pejabat kantor catatan sipil yang hanya berpegang pada petunjuk teknis terkait dengan pencatatan perkawinan, dengan mengabaikan ketentuan 
peraturan perundang-undangan yang berlaku perihal pencatatan perkawinan dan pencatatan perjanjian perkawinan tersebut. Hambatan tersebut terjadi oleh karena di dalam Formulir (Formulir F2.12) yang digunakan untuk melakukan pencatatan perkawinan tersebut tidak terdapat kolom mengenai perjanjian perkawinan. ${ }^{7}$

Demikian juga terhadap pencatatan perjanjian perkawinan yang dibuat pada saat perkawinan berlangsung tentunya akan menghadapi hambatan yang sama sepanjang belum ada ketentuan baru yang mengatur tata cara pencatatan perjanjian perkawinan yang dibuat pada saat perkawinan berlangsung tersebut. Untuk mengatasi hambatan tersebut tentunya Menteri Dalam Negeri harus segera mengeluarkan peraturan terkait dengan pencatatan perjanjian perkawinan, termasuk mengenai pencatatan perjanjian perkawinan yang dibuat sepanjang perkawinan, yang segera diikuti dengan dikeluarkannya petunjuk teknis perihal pencatatan perjanjian perkawinan tersebut. Oleh karena itu sepanjang belum adanya ketentuan mengenai pencatatan perjanjian perkawinan yang dibuat pada saat perkawinan berlangsung maka tentunya pencatatannya belum dapat dilakukan, dan apabila perjanjian perkawinan tersebut belum dicatat maka perjanjian perkawinan tersebut tidak mengikat pihak ketiga dan hanya berlaku dianatara para pihak. ${ }^{8}$

Akibat Hukum Pembuatan Akta Perjanjian Perkawinan Setelah Kawin Sebelum Dan Pasca Putusan Mahkamah Konstitusi Nomor 69/PUU-XIII/2015 Terhadap Status Harta Bersama Dan Pihak Ketiga Yang Dibuat Dihadapan Notaris

Akibat Hukum Pembuatan Akta Perjanjian Perkawinan Setelah Kawin Sebelum Putusan Mahkamah Konstitusi Nomor 69/PUU-XIII/2015 Terhadap Status Harta Bersama Dan Pihak Ketiga

Pembuatan akta perjanjian perkawinan pada umumnya menimbulkan akibat hukum terhadap status harta maupun terhadap pihak ketiga yang berkepentingan. Dari hasil penelitian yang dilakukan penulis mengenai Penetapan Pengadilan Negeri Nomor207/Pdt.P/2005/PN.Jkt.Tim dan Penetapan Pengadilan Negeri Nomor459/Pdt.P/2007PN.Jkt.Tim. menemukan beberapa Akibat hukum dari Penetapan Pengadilan Negeri tersebut yaitu:

\section{Akibat Hukum Terhadap Status Harta}

Adapun akibat hukum terhadap status harta dari kedua Penetapan Pengadilan Negeri Nomor207/Pdt.P/2005/PN.Jkt.Tim dan Penetapan Pengadilan Negeri Nomor459/Pdt.P/2007PN.Jkt.Tim ialah terjadinya pemisahan harta yang sebelumnya

\footnotetext{
7 Alwesius, ... Op. Cit.

${ }^{8}$ Ibid.
} 
menjadi harta bersama menjadi harta masing-masing para pihak dan terhadap harta-harta lain yang kemudian hari timbul setelah tanggal penetapan tersebut tetap terpisah satu dengan yang lainnya, sehingga tidak ada lagi berstatus harta bersama.

\section{Akibat Hukum Terhadap Pihak Ketiga}

Berlakunya perjanjian perkawinan bagi pihak ketiga diatur dalam Pasal 152 Kitab Undang-Undang Hukum Perdata yang berbunyi : "Ketentuan yang tercantum dalam perjanjian perkawinan, yang mengandung penyimpangan dari persatuan menurut UndangUndang seluruhnya atau untuk sebagian, tidak akan berlalu terhadap pihak ketiga, sebelum hari ketentuan-ketentuan itu dilakukan dalam suatu register umum, yang harus diselenggarakan untuk itu di Kepaniteraan pada Pengadilan Negeri, yang mana dalam daerah hukumnya perkawinan itu telah dilangsungkan, atau, jika perkawinan berlangsung di luar negeri, di Kepaniteraan dimana akta perkawinan dibukukannya". Dari ketentuan di atas dapat diketahui bahwa suatu perjanjian perkawinan dapat juga berlaku bagi pihak ketiga, setelah perjanjian perkawinan tersebut didaftar di Kepaniteraan Pengadilan Negeri.

Jadi berdasarkan ketentuan Pasal 147 Juncto Pasal 152 Kitab Undang-Undang Hukum Perdata dapat disimpulkan bahwa sejak perkawinan dilangsungkan perjanjian perkawinan hanya berlaku bagi para pihak yang membuatnya yaitu pasangan suami istri, sedangkan perjanjian perkawinan baru berlaku terhadap pihak ketiga sejak didaftarkan di Kepaniteraan Pengadilan Negeri.

Namun setelah barlakunya Undang-Undang Nomor 1 Tahun 1974 Tentang Perkawinan maka pendaftaran atau pencatatan akta perjanjian perkawinan beralih ke Dinas Kependudukan dan Pencatatan Sipil atau Kantor Urusan Agama (KUA). Menurut Pasal 29 ayat (1) Undang-Undang Nomor 1 Tahun 1974 Tentang Perkawinan, sebuah perjanjian perkawinan dapat mengikat terhadap pihak ketiga apabila perjanjian tersebut disahkan atau didaftarkan kepada pegawai pencatat perkawinan maka dengan sendirinya perjanjian perkawinan tersebut mempunyai kekuatan yang mengikat terhadap pihak ketiga.

Hal yang sama juga ditegaskan dalam Kompilasi Hukum Islam pada Pasal 50 disebutkan perjanjian perkawinan mengenai harta, mengikat kepada para pihak dan pihak ketiga, terhitung mulai tanggal dilangsungkannya perkawinan di hadapan pegawi pencatat nikah. Maka dengan keadaan tersebut akibat hukumnya terhadap pihak ketiga adalah pihak ketiga selama perjanjian perkawinan belum didaftarkan dapat saja menganggap bahwa perkawinan berlangsung dengan harta persatuan. Sehingga apabila terjadi persangkutan 


\section{LEX Renaissance No. 1 VOL. 2 JANUARI 2017: 16 - 34}

utang dengan suami atau istri, penyelesainannya dilakukan dengan melibatkan harta bersama.

Sedangkan pembuatan perjanjian perkawinan yang didasarkan penetapan Pengadilan Negeri yang hubungannya terhadap pihak ketiga akan berlaku sejak tanggal penetapan Pengadilan Negeri dikeluarkan, sehingga pihak ketiga dalam hal ini tidak mendapatkan kerugian jika terjadi sesuatu dikemudian hari, karena sudah ada kesepakatan pemisahan harta sebelumnya, dengan alasan-alasan seperti yang diajukan di Pengadilan Negeri Jakarta Timur. Namun demikian jika pihak ketiga (kreditur) bisa membuktikan bahwa yang dijadikan jaminan hutang atau diperjanjikan sebagai jaminan dalam bentuk apapun diperoleh sebelum atau sudah ada pada saat dikeluarkan penetapan Pengadilan Negeri maka pihak ketiga (kreditur) dapat menuntut pelunasannya terhadap harta bersama dari suami istri. Sedangkan utang yang dibuat oleh salah satu pihak suami atau istri setelah penetapan tersebut maka pihak ketiga dapat ditagih pelunasannya terhadap pihak suami atau pihak istri yang berhutang.

Perjanjian kawin setelah perkawinan diadakan tidak hanya mengatur sebab akibat harta perkawinan setelah perkawinan berlangsung tetapi juga terhadap pihak ketiga. Misalnya saja salah satu pihak suami atau istri yang mempunyai tanah dan bangunan hak milik mengadakan penjualan tanah dan bangunan, maka harus diperhatikan si penjual memiliki tanah dan bangunan sebelum atau sesudah penetapan tersebut sehingga jangan sampai pihak ketiga yaitu pembeli dalam hal ini dirugikan atau dituntut oleh salah satu pihak dari pasangan suami-istri tersebut dari penjual tanpa adanya persetujuan untuk menjual karena statusnya harta bersama karena tanah dan bangunan dimiliki sebelum dibuatnya penetapan Pengadilan Negeri.

Mengenai penetapan Pengadilan Negeri Jakarta Timur Nomor 207/Pdt.P/2005/PN.Jkt.Tim, misalnya ada kaitanya dengan pihak ketiga yaitu kreditur. Para pemohon membuat perjanjian kawin pemisahan harta dikarenakan pemohon I (suami) yang bekerja dalam jabatannya sebagai direktur dalam suatu perseroan Perusahaan Terbatas dengan tanggung jawab sampai keharta-harta pribadi. Jika dikemudian hari mengadakan hubungan hukum terhadap pihak lain setelah penetapan tersebut dan dapat menimbulkan kerugian bagi Perseroan dimana tempat pemohon I (suami) bekerja maka tanggung jawabnya sebatas pada harta-harta pribadi pemohon I (suami) tidak sampai kepada hartaharta istri. Untuk penetapan Pengadilan Negeri Jakarta Timur Nomor 459/Pdt.P/2007/PN.Jkt.Tim misalnya ada hubungannya terhadap pihak ketiga yaitu orang tua. Jika terjadi hibah atau warisan berupa tanah dari orang tua kepada pemohon II (istri) 
sebelum penetapan tersebut maka secara hukum terjadi percampuran harta, apabila tidak dialihkan kepada subyek yang berhak sesuai dengan Pasal 21 Undang-Undang Dasar Pokok-Pokok Agraria Nomor 5 Tahun 1960 dalam jangka waktu 1 (satu) tahun hibah atau warisan berupa tanah maka tanah tersebut hapus karena hukum dan tanahnya jatuh pada Negara. Sehingga para pemohon mengantisipasi dengan cara mengajukan pembuatan perjanjian kawin berupa penetapan pengadilan Negeri. Penetapan Pengadilan Negeri tersebut tidak akan merugikan pihak ketiga apabila dilaksanakan dengan ketentuan bahwa harta yang diperoleh suami istri sebelum keluarnya penetapan Pengadilan Negeri tetap merupakan harta bersama.

Menurut hemat penulis perjanjian perkawinan setelah perkawinan diadakan untuk mengatur sebab akibat harta perkawinan setelah perkawinan terjadi, manakala terdapat sejumlah harta yang tidak sama atau lebih besar pada satu pihak suami atau istri. Jadi perjanjian perkawinan setelah kawin pada dasarnya selalu terkait dengan persoalan harta dalam perkawinan.

\section{Akibat Hukum Pembuatan Akta Perjanjian Perkawinan Pasca Putusan Mahkamah Konstitusi Nomor 69/PUU-XIII/2015 Terhadap Status Harta Bersama Dan Pihak Ketiga}

\section{Akibat Hukum Terhadap Status Harta}

Akibat hukum pembuatan perjanjian perkawinan setalah kawin terhadap status harta inheren (berkaitan erat) dengan waktu mulai berlakunya perjanjian tersebut. Di atas telah diuraikan sebelumnya bahwa untuk perjanjian perkawinan yang dibuat sebelum atau pada saat perkawinan, sesuai ketentuan Pasal 29 Undang-Undang Perkawinan, perjanjian perkawinan mulai berlaku sejak perkawinan dilangsungkan. Lalu bagaimana dengan perjanjian perkawinan yang dibuat sepanjang perkawinan pasca putusan MK, apakah perjanjian perkawinan tersebut mulai berlaku sejak pembuatan perjanjian perkawinan atau berlaku surut sejak tanggal perkawinan.

Jika melihat Putusan Mahkamah Konstitusi Nomor 69/PUU-XIII/2015 yang dalam amarnya menyebutkan bahwa "Perjanjian tersebut mulai berlaku sejak perkawinan dilangsungkan, kecuali ditentukan lain dalam Perjanjian Perkawinan". Maka jelas bahwa terhadap perjanjian perkawinan yang dibuat sepanjang perkawinan juga berlaku mulai terhitung sejak perkawinan dilangusngkan, kecuali ditentukan lain di dalam perjanjian perkawinan yang bersangkutan. Pasal 29 ayat (3) Undang-Undang Nomor 1 Tahun 1974 Perkawinan yang berbunyi "Perjanjian perkawinan mulai berlaku sejak perkawinan dilangusngkan." menurut Mahkamah Konstitusi harus dimaknai bahwa berbunyi 


\section{IEx Renaissance No. 1 VOL. 2 JANUARI 2017: 16 - 34}

"Perjanjian perkawinan mulai berlaku sejak perkawinan dilangsungkan, kecuali ditentukan lain dalam Perjanjian Perkawinan." Bila tidak dimaknai sebagaimana tafsir Mahkamah Konstitusi maka terhadap pasal-pasal demikian itu dinyatakan berntentangan dengan UUD 1945.

Dibuatnya perjanjian perkawinan setelah kawin tersebut tanpa dengan menentukan keberlakuannya maka konsekuensi hukumnya perjanjian tersebut mulai berlau sejak perkawinan dilangsungkan yang diikuti dengan status harta bersama menjadi terpisah bila dikehendaki kedua belah pihak dalam perjanjian tersebut, tanpa harus mendapatkan penetapan pengadilan terkait pemisahan harta. Karena materi muatan perjanjian yang dibuat oleh para pihak yaitu perjanjian pemisahan harta yang dalam prinsip kebebasan berkontrak para pihak diberikan kebebasan untuk menentukan materi muatannya, bila dalam hal ini para pihak telah menentukan bahwa harta yang tadinya telah berstatus harta bersama menjadi harta masing-masing pihak, maka secara hukum dapat dibenarkan, sehingga harta yang dimikian itupun yang diperoleh oleh suami-istri selama perkawinan berlangsung baik sebelum atau setelah dibuatnya perjanjian perkawinan menjadi milik masing-masing suamiistri.

\section{Akibat Hukum Terhadap Pihak Ketiga}

Putusan Mahmkamah Konstitusi dalam hal ini tidak saja mengatur mengenai akibat hukum perjanjian perkawinan setelah kawin terhadap status harta, namun juga mengatur secara implisit akibat hukum terhadap pihak ketiga. Putusan MK tersebut dalam amarnya menyebutkan bahwa "Pada waktu, sebelum dilangsungkan atau selama dalam ikatan perkawinan kedua belah pihak atas persetujuan bersama dapat mengajukan perjanjian tertulis yang disahkan oleh pegawai pencatatan perkawinan atau Notaris, setelah mana isinya berlaku juga terhadap pihak ketiga sepanjang pihak ketiga tersangkut.

Selanjutnya yang menjadi permasalahan dalam hal ini ialah bagaimana caranya untuk dapat mengetahui adanya pihak ketiga yang dirugikan terkait dengan pembuatan perjanjian perkawinan. Karena Putusan Mahkamah Konstitusi maupun Undang-Undang Perkawinan tidak mengatur hal tersebut.

Undang-Undang Perkawinan hanya menentukan bahwa apabila perjajian perkawinan tersebut telah disahkan oleh pegawai pencatatan perkawinan maka perjanjian perkawinan tersebut baru dapat mengikat pihak ketiga. Maka terhadap hal ini sungguuh sangat tidak adil bila seandainya terdapat suatu perjanjian perkawinan yang dibuat sepanjang perkawinan tersebut merugikan pihak ketiga, kemudian atas perjanjian perkawinan tersebut dilakukan pencatatan di Kantor Catatan Sipil. Dengan dilakukannya 
pencatatan sehingga pihak ketiga terikat atas perjanjian perkawinan tersebut, sementara perjanjian perkawinan itu merugikan dirinya.

Berkaitan dengan hal tersebut menurut Alwesius pembuatan perjanjian perkawinan demikian itu tentunya Notaris dalam hal ini tidak serta merta begitu saja memberikan bantuannya untuk membuat perjanjian perkawinan. Karena Notaris harus memperoleh kepastian bahwa perjanjian perkawinan yang dibuat tersebut tidak merugikan pihak ketiga.

Berkaitan dengan hal tersebut Alwesius juga berpendapat, sepanjang belum diatur tatacara tersebut maka sebaiknya para Notaris di dalam melayani permintaan pembuatan akta perjanjian perkawinan terlebih dahulu meminta kepada para pihak untuk melakukan pengumuman di dalam surat kabar yang terbit di kota dimana para pihak berdomisili, yang mempunyai peredaran yang luas dan tentunya ditempatkan pada halaman yang mudah terbaca. ${ }^{9}$

Sejalan dengan itu, guna melindugi pihak ketiga Habib Adjie berpendapat bahwa ketika Notaris diminta untuk membuat perjanjian perkawinan yang mengacu pada Putusan MK ada 2 (dua) hal yang harus di perhatikan oleh Notaris yaitu: 1) Meminta daftar inventaris harta yang diperoleh selama dalam ikatan perkawinan yang akan dicantumkan dalam akta; 2) Adanya atau membuat pernyataan bahwa harta-harta tersebut tidak perna ditransaksikan dengan cara dan bentuk apapun, untuk dan kepada siapapun.

Berdasarkan urian pendapat ahli di atas dapat dilihat bahwa adanya suatu kekawatiran dikalangan para Notaris maupun akademisi terhadap akibat hukum atas Putusan Mahkamah Konstitusi tersebut sepanjang pemerintah belum menetapkan peraturan teknis terkait mekanisme hukum pembuatan perjanjian perkawinan pasca putusan Mahkamah Konstitusi yang berkaitan dengan kekuatan mengikat perjanjian perkawinan terhadap pihak ketiga apabila perjanjian tersebut dibuat berdasarkan Putusan Mahkamah Konstitusi yang memberikan tafsir konstitusionalnya yang menyatakan perjanjian perkawinana juga dapat dibuat dalam masa ikatan perkawinan berlangsung dan juga mengikat pihak ketiga yang terkait.

Menurut hemat penulis kekawatiran tersebut timbul disebabkan oleh norma hukum dalam perjanjian perkawinan agar mengikat pihak ketiga harus didaftarkan di Kantor Catatan Sipil atau Kantor Urusan Agama, dan pendaftaran atau pencatatan tersebut berlaku juga untuk akta perjanjian perkawinan yang dibuat sebelum perkawinan dilakukan atau 
berdasarkan perintah pengadilan, dengan demikian perjanjian perkawinan yang dibuat dengan mengacu pada Putusan Mahkamah Konstitusi tersebut agar mengikat pihak ketiga harus didaftarkan di Kantor Catatan Sipil atau Kantor Urusan Agama.

Karena Putusan Mahkamah Konstitusi demikian itu tidak memerintahkan apapun tentang pendaftaran pencatatannya, apakah serta merta harus didaftarkan atau menunggu aturan hukum lanjutan untuk pendaftaran/pencatatannya. ${ }^{10}$ Habib Adjie bependapat yang sekaligus memberikan solusi terkait hal tersebut yaitu bahwa setelah perjanjian kawin tersebut dibuat yang menagcu pada Putusan Mahkamah Konstitusi, maka ajukan permohonan penetapan ke pengadilan agar memerintahkan kepada Kantor Catatan Sipil atau Kantor Urusan Agama mendaftrakannya atau mencatatkannya. Sehingga dengan demikian akibat hukum perjajian perkawinan tersebut dapat memberikan kepastian hukum bagi pihak ketiga.

\section{Penutup}

Berdasarkan pemaparan di atas, maka dapat disimupkan bahwa pertama, Implikasi Putusan Mahkamah Konstitusi Nomor 69/PUU-XIII/2015 terhadap pembuatan akta perjanjian perkawinan setelah kawin yang dibuat dihadapan Notaris merubah mekanisme hukum pembuatan perjanjian perkawinan yang kini dapat dibuat selama ikatan perkawinan berlangsung oleh Notaris tanpa harus di dahului dengan penetapan pengadilan yang berwenang. Karena pada mulanya ketentuan Pasal-pasal dalam Undang-Undang Perkawinan walaupun hanya mengatur mengenai perjanjian perkawinan yang dapat dibuat pada waktu atau sebelum perkawinan dilangsungkan, namun fenomena yang terjadi di masyrakat dapat dijumpai perjanjian perkawinan yang dibuat pada saat perkawinan berlangsung yang dengan alasan tertentu antara suami-istri tersebut baru membuat Perjanjian perkawinan, yang harus didahului dengan mangajukan permohonan ke pengadilan yang berwenang agar mendapatkan suatu penetapan dari hakim, yang kemudian setelah itu barulah Notaris dapat membuatkan akta perjanjian perkawinan setelah kawin berdasarkan penetapan pengadilan tersebut.

Kedua, akibat hukum pembuatan akta perjanjian perkawinan setelah kawin sebelum dan pasca Putusan Mahkamah Konstitusi Nomor 69/PUU-XIII/2015 terhadap status harta bersama dan pihak ketiga yang dibuat di hadapan Notaris antara lain sebagai berikut: (1)

${ }^{10}$ Habib Adjie, Memahami Kedudukan Hukum: Perjanjian Perkawinan Pasca Putusan Mabkamah Konstitusi Nomor 69/PUU-XIII/ 2015 tentang Pengujian Undang-Undang Nomor 5 Tabun 1960 tentang Peraturan Dasar Pokok-pokok. Agraria dan Undang-Undang Nomor 1 Tahun 1974 tentang Perkawinan, materi disampaikan pada saat seminar yang diselenggarakan oleh Ikatan Notaris Indonesia di Hotel Grasia Semarang pada tanggal 19 Desember 2016. 
Akibat hukum pembuatan akta perjanjian perkawinan setelah kawin sebelum Putusan Mahkamah Konstitusi Nomor 69/PUU-XIII/2015 yang didasarkan atas penetapan Pengadilan Negeri Jakarta Timur terhadap status harta bersama dan pihak ketiga adalah adanya perubahan terhadap status harta suami-istri yang semula merupakan harta bersama, menjadi harta pribadi masing-masing suami-istri sesuai dengan yang disepakati dan didasarkan dalam penetapan dari Pengadilan Negeri dan perjanjian perkawinan yang dibuat setelah kawin yang didasarkan penetapan Pengadilan Negeri Jakarta Timur berlaku dan mengikat kepada kedua belah pihak yang membuat dan mengikat pihak ketiga sepanjang Penetapan pembuatan perjanjian perkawinan setelah kawin tersebut tidak merugikan pihak ketiga. (2) Akibat hukum pembuatan akta perjanjian perkawinan setelah kawin pasca Putusan Mahkamah Konstitusi Nomor 69/PUU-XIII/2015 terhadap status harta bersama dan pihak ketiga adalah pembuatan perjanjian perkawinan setalah kawin terhadap status harta bersama inheren (berkaitan erat) dengan waktu mulai berlakunya perjanjian tersebut. Berdasarkan putusan Mahkamah Konstitusi Perjanjian perkawinan mulai berlaku sejak perkawinan dilangsungkan, kecuali ditentukan lain dalam Perjanjian Perkawinan. Artinya bahwa apabila para pihak tidak menentukan kapan perjanjian perkawinan tersebut mulai berlaku maka demi hukum perjanjian perkawinan tersebut mulai berlaku terhitung sejak perkawinan dilangsungkan. Dengan demikian akibat hukum terhadap status harta bersama dibuatnya suatu perjanjian perkawinan setelah kawin tersebut yang mulai berlau sejak perkawinan tersebut dilangsungkan diikuti dengan status harta bersama menjadi terpisah bila dikehendaki kedua belah pihak dalam perjanjian tersebut, begitu juga terhadap harta yang akan diperoleh dikemudian hari tetap milik masing-masing pihak, tanpa harus mendapatkan penetapan pengadilan terkait pemisahan harta. Kemudian akibat hukum pembuatan perjanjian perkawinan berdasarkan Putusan Mahkamah Konstitusi berlaku dan mengikat pihak ketiga. Pembuatan perjanjian perkawinan demikian itu tidak boleh merugikan pihak ketiga. karena pembuatan perjanjian perkawinan sepanjang perkawinan berlangsung membawa akibat hukum terhadap perubahan status hukum harta benda yang terdapat atau diperoleh di dalam perkawinan tersebut.

\section{Daftar Pustaka}

Habib Adjie, Memahami Kedudukan Hukum: Perjanjian Perkawinan Pasca Putusan Mahkamah Konstitusi Nomor 69/PUU-XIII/2015 tentang Pengujian UndangUndang Nomor 5 Tahun 1960 tentang Peraturan Dasar Pokok-pokok Agraria dan Undang-Undang Nomor 1 Tahun 1974 tentang Perkawinan, materi disampaikan 
pada saat seminar yang diselenggarakan oleh Ikatan Notaris Indonesia di Hotel Grasia Semarang pada tanggal 19 Desember 2016.

Indonesia, Undang-Undang Nomor 24 Tahun 2003 tentang Mahkamah Konstitusi sebagaimana telah diubah dengan Undang-Undang Nomor 8 Tahun 2011 tentang Perubahan Atas Undang-Undang Nomor 24 Tahun 2003 tentang Mahkamah Konstitusi.

Alwesius, Pembuatan Perjanjian Perkawinan Pasca Putusan Mahkamah Konstitusi http://alwesius.blogspot.co.id/2016/11/pembuatan-perjanjian-perkawinanpasca.html, diakses pada tanggal 3 Januari 2017.

Undang-Undang Nomor 30 Tahun 2004 tentang Jabatan Notaris sebagaimana telah diubah dengan Undang-Undang Nomor 2 Tahun 2014 tentang Perubahan atas UndangUndang Nomor 30 Tahun 2004 tentang Jabatan Notaris menyebutkan bahwa Notaris adalah Pejabat Umum yang berwenang untuk membuat akta otentik dan kewenangan lainnya sebagaimana dimaksud dalam Undang-Undang ini.

H.B. Sutopo. Metodologi Penelitian Hukum Kualitaif Bagian II, Surakarta : UNS Press, 1998.

Suryono Sukanto \& Sri Mamuji, Penelitian Hukum Normatif, cet empat balas Jakarta: PT Raja Grafindo Persada, 2012. 